\title{
Treatment of cystoid macular edema secondary to chronic non-infectious intermediate uveitis with an intraocular dexamethasone implant
}

\author{
Tratamento do edema macular cistóide secundário à uveíte intermediária não infecciosa com implante \\ intraocular de dexametasona
}

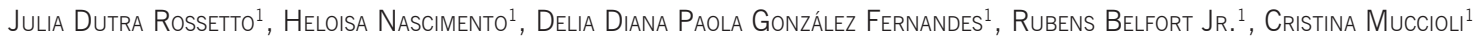

\begin{abstract}
Purpose: To evaluate the use of a slow-release dexamethasone 0.7-mg intravitreal implant for cystoid macular edema (CME) secondary to intermediate uveitis and refractory to systemic steroids.

Methods: A retrospective study of the best-corrected visual acuity (BCVA), intraocular inflammation, intraocular pressure (IOP), fundus photography, optical coherence tomography (OCT), inflammation, and adverse reactions of five patients (women, mean age of 35 years) with cystoid macular edema treated with a dexamethasone implant. Patients were evaluated in seven visits until the $150^{\text {th }}$ day after the implant.

Results: Four patients had bilateral pars planitis and one had bilateral intermediate uveitis associated with juvenile idiopathic arthritis. Six dexamethasone devices were implanted, under topical anesthesia (one each in six eyes, five patients). The mean follow-up time was 5 months. The best-corrected visual acuity improved in all eyes that received an implant, with five having improvements of two or more lines. Optical coherence tomography showed thinning of the macula in all eyes treated, and we saw a correlation between the best-corrected visual acuity and retinal thinning. No serious adverse events occurred and no significant increase in intraocular pressure was observed.

Conclusions: Slow-release dexamethasone intravitreal implants can effectively treat CME secondary to intermediate uveitis and refractory to systemic steroids.
\end{abstract}

Keywords: Macular edema/etiology; Uveitis/complications; Tomography, optical coherence; Dexamethasone/therapeutic use; Visual acuity

\section{RESUMO}

Objetivos: Avaliar o implante intravítreo de liberação lenta de dexametasona 0,7 mg no tratamento do edema macular cistóide (EMC) secundário à uveíte intermediária refratária a corticosteroides orais.

Métodos: Estudo retrospectivo da acuidadevisual melhor corrigida, inflamação intraocular, pressão intraocular (PIO), retinografia, tomografia de coerência óptica (OCT), inflamação e reações adversas de cinco pacientes (mulheres, idade média 35 anos) com o edema macular cistóide tratado com implante de dexametasona. Pacientes foram avaliados em 7 consultas até $0150^{\circ}$ dia pós implante.

Rsultados: Quatro pacientes apresentaram parsplanite bilateral e um, uveíte intermediária bilateral associada à artriteidiopáticajuvenil. Seis implantes foram inseridos sob anestesia tópica. O tempo médio de acompanhamento foi de 5 meses. A acuidade visual melhorou em todos os olhos. A tomografia de coerência óptica mostrou afinamento da mácula em todos os ol hos e houve correlação entre a acuidade visual e a retina mais fina. Não ocorreu evento adverso grave. Não ocorreu aumento significativo na pressão intraocular.

Conclusão: O implante intravítreo é eficaz no tratamento do edema macular cistóide secundário a uveíte intermediária refratária a esteróides sistêmicos.

Descritores: Edemamacular/etiologia; Uveíte/complicacões; Tomografia decoerência óptica; Dexametasona/uso terapêutico; Acuidade visual

\section{INTRODUCTION}

Corticosteroids are the mainstay of non-infectious uveitis treatment. The use of local corticosteroids minimizes systemic adverse effects, but local use can lead to increased intraocular pressure (IOP), cataract, and endophthalmitis(1,2). Cystoid macular edema (CME) is a major contributor to decreased visual acuity (VA) secondary to uveitis, and is usually treated with systemic, periocular, or intraocular steroids ${ }^{(1,2)}$.

The dexamethasone 0.7-mg implant (Ozurdex ${ }^{\circledR}$ Allergan, Inc., CA, USA) is an innovative slow-release system that is biodegradable. It can be implanted through an injection system, and implantation can be performed on an outpatient basis.

Dexamethasone has potent anti-inflammatory properties and a history of favorable effects for the treatment of macular edema ${ }^{(3,4)}$. Previous studies have shown that implantation of the slow-release dexamethasone implant can improve visual acuity (VA) and macular thickness ${ }^{(3,4)}$.

We evaluated the tolerability and effectiveness of the biodegradable intravitreal implant of $0.7 \mathrm{mg}$ dexamethasone in patients with refractory CME secondary to intermediate uveitis.

\section{METHODS}

We retrospectively reviewed the medical records of patients with chronic CME secondary to non-infectious uveitis and refractory to systemic treatment with corticosteroids and/or cytotoxic drugs. The patients who received the dexamethasone implant had a minimum age of 18 years and a best-corrected VA (BCVA) of 20/60 or worse.

We evaluated patients demographics, etiology of the inflammation, BCVA, previous therapies, results of ocular examinations [inclu-
Funding: No specific financial support was available for this study.

Disclosure of potential conflicts of interest: None of the authors have any potential conflict of interest to disclose.

Corresponding author: Julia D. Rossetto. Rua Botucatu, 821 - São Paulo, SP - 04023-062 - Brazil E-mail: julia_rossetto@hotmail.com

Approved by the following research ethics committee: UNIFESP/EPM (319.804) 
ding biomicroscopy, IOP, indirect ophthalmoscopy, and optical coherence tomography $(\mathrm{OCT})]$, and adverse reactions.

All patients had previously received systemic immunosuppressive therapy, including oral corticosteroids and methotrexate for patients 1 and 2; oral corticosteroids and ciclosporin for patients 3 and 4; and intravenous and oral corticosteroids, and azathioprine for patient 5. All patients were refractory to these treatments, as measured as BCVA improvement less than two lines at a minimum follow-up of 5 months.

Two patients had undergone a previous glaucoma surgery. Patient 1 had undergone a trabeculectomy 6 months prior, and on the same eye the dexamethasone device was implanted. Patient 3 had undergone phacoemulsification one year prior, and on the same eye the dexamethasone device was implanted. She had also received an Ahmed valve implant (New World Medical, Inc., CA, USA) 5 years prior, and on the same eye the dexamethasone device was implanted.

To determine the etiologies of the infectious and noninfectious diseases, analysis was performed using clinical, laboratory, and radiographic data.

The biodegradable dexamethasone implant was used according to published data(3-7) and according to the manufacturer's instructions (http://www.allergan.com/assets/pdf/ozurdex_pi.pdf).

After the implantation procedure, $0.3 \%$ gatifloxacin drops were administered for 4 days. The patients were evaluated in seven postoperative visits, occurring on days $1,15,30,60,90,120$, and 150 following implantation. During all visits, BCVA was measured, and anterior and posterior slit-lamp examination, Goldmann tonometry, dilated fundus examination, and OCT were performed. All patients were assessed for ocular inflammation and the need for additional intravitreal injections.

\section{RESULTS}

Six eyes of five patients received a dexamethasone 0.7-mg sustained-release intravitreal implant to treat intermediate non-infectious uveitis. Patient demographic data, diagnosis, and examination findings are summarized in table 1. The mean follow-up time post-implantation was 5 months.

BCVA improved in all eyes, with five eyes having an improvement of two or more lines of VA. OCT measurement of macular thickness revealed improvement in all eyes (Figure 1). We identified a correlation between BCVA and thinning of the macula, as evaluated by OCT. The mean duration of implant effectiveness was 3.6 months (range 3-4 months), with a standard deviation of 0.55.

No serious ocular or systemic adverse events occurred during the follow-up period. Subconjunctival hemorrhages developed at the site of implant injection in two cases.

IOP observed during the follow-up visits was $22 \mathrm{mmHg}$ or less in all eyes, and the range of IOP was between 2 and $6 \mathrm{mmHg}$ in all patients. Two patients had a $6 \mathrm{mmHg}$ range in IOP and also previously had glaucoma surgery. The other patients had variations in IOP of $3 \mathrm{mmHg}$ or less (Table 2).

\section{DISCUSSION}

Treating patients with severe uveitis, the fifth leading cause of vision loss in the United States, is a major challenge in ophthalmology. Although the administration of systemic corticosteroids, immunosuppressive agents, or a combination of both is considered the gold standard treatment for this disease, complications and side effects may result from long-term treatment and are major concerns. These drugs may also not be available for the treatment of ocular diseases in developing countries.

Systemic corticosteroids are often accompanied by a poor safety profile characterized by multiple adverse effects, such as fluid retention, hypertension, hyperglycemia, osteoporosis, mood changes, psychosis, and greater susceptibility to infections ${ }^{(5)}$. Immunosuppressive agents can also be unsafe for women of child bearing age, because these drugs increase the risk of fetal malformations.

The Systemic Immunosuppressive Therapy for Eye Diseases study recently reported data on both overall and cancer-related mortality following inflammatory disease treatment with immunosuppressants or biologic drugs ${ }^{(9)}$. Preliminary findings from this study have suggested that cancer and total mortality may increase with the use of anti-tumor necrosis factor agents, though this must be confirmed in further studies. In addition to these safety concerns, biologic drugs also pose difficulties with respect to third-party payment and their overall $\operatorname{cost}^{(9,10)}$. For these reasons and due to the absence of solid medical evidence, biologic treatments may not be the treatment of choice for uveitis.

Uveitis is particularly difficult to treat due to the blood-retinal barrier, which significantly reduces the ability of topical and systemic medications to reach effective concentrations in posterior ocular structures. In addition, adequate vitreous and retinal concentrations of corticosteroids for the treatment of posterior inflammation should ideally be achieved through local therapies that do not have adverse systemic effects ${ }^{(5)}$. Due to these concerns, local treatment for uveitis has gained popularity in recent years. Local injections of corticosteroids, such as intravitreal injection of triamcinolone, can effectively control uveitis and eliminate the use of systemic medications ${ }^{(11)}$. Moreover, the Ozurdex implant is increasingly being used as a local therapy to treat ocular diseases. Safety and efficacy of Ozurdex in the treatment of macular edema due to retinal vein occlusion has been demonstrated, ${ }_{1}^{(7)}$ and the US Food and Drug Administration has approved it for intravitreal use in macular edema secondary to non-infectious uveitis or retinal vein occlusion. The implant has also been approved in Brazil. This medication has also been tested off-label in the treatment of non-necrotizing scleritis with positive results ${ }^{(6)}$.

Previous studies, such as the Multicenter Uveitis Steroid Treatment (MUST) trial(8), which were designed to compare the fluocinolone acetonide implant to standard systemic therapy for the treatment of patients with non-infectious intermediate uveitis, posterior uveitis, or panuveitis, found that both treatments improved vision similarly over two years.

In this study, we treated five patients with an intravitreal dexamethasone implant (Ozurdex). Four of these patients had idiopathic

Table 1. Patient demographic data

\begin{tabular}{|c|c|c|c|c|c|c|c|}
\hline Patient & Age & Diagnosis & Basal VA & ОСт $(\mu)$ & Follow-up (months) & Final VA & Final OCT $(\mu)$ \\
\hline \multirow[t]{2}{*}{1} & 19 & IIU & $20 / 400$ & 670 & 5 & $20 / 80$ & 213 \\
\hline & & & $20 / 60$ & 461 & & $20 / 40$ & 217 \\
\hline 2 & 22 & JIA & $20 / 60$ & 558 & 5 & $20 / 40$ & 259 \\
\hline 3 & 48 & IIU & 20/160 & 450 & 5 & $20 / 80$ & 273 \\
\hline 4 & 66 & IIU & $20 / 400$ & 472 & 5 & 20/100 & 345 \\
\hline 5 & 20 & $\| U$ & $20 / 80$ & 404 & 5 & $20 / 50$ & 261 \\
\hline
\end{tabular}

$\| \cup=$ idiopathic intermediate uveitis; $\| \mathrm{A}=$ juvenile idiopathic arthritis. 

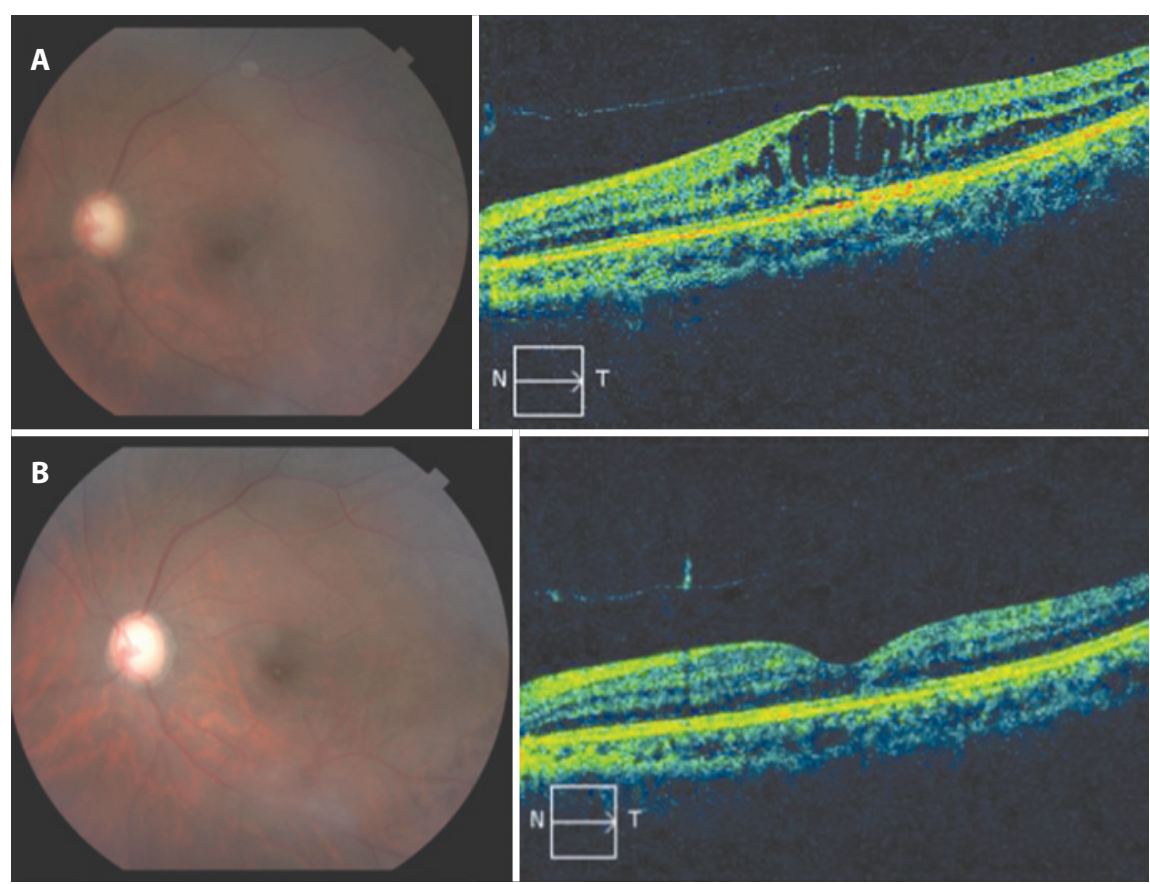

$\mathrm{N}=$ nasal; $T=$ temporal

Figure 1. Patient 3 - representative case. A) OCT of the left eye before treatment. B) OCT of the left eye 5 months after treatment.

\section{Table 2. Visual acuity, IOP, and OCT follow-up}

\begin{tabular}{|c|c|c|c|c|c|c|c|c|c|}
\hline Patient & Initial VA & $15^{\text {th }}$ day VA & $120^{\text {th }}$ day VA & Initial IOP & $15^{\text {th }}$ day IOP & $120^{\text {th }}$ day IOP & Initial OCT & $15^{\text {th }}$ day OCT & $120^{\text {th }}$ day $O C T$ \\
\hline \multirow[t]{2}{*}{1} & $20 / 400$ & $20 / 200$ & $20 / 80$ & 12 & 12 & 15 & 670 & 470 & 222 \\
\hline & $20 / 60$ & $20 / 60$ & $20 / 32$ & 16 & 22 & 20 & 461 & 298 & 201 \\
\hline 2 & $20 / 60$ & $20 / 60$ & $20 / 40$ & 16 & 18 & 16 & 558 & 412 & 239 \\
\hline 3 & $20 / 160$ & $20 / 80$ & $20 / 60$ & 15 & 16 & 14 & 450 & 337 & 244 \\
\hline 4 & $20 / 400$ & $20 / 100$ & $20 / 60$ & 12 & 14 & 14 & 472 & 309 & 271 \\
\hline 5 & 20/80 & $20 / 40$ & $20 / 32$ & 14 & 14 & 16 & 404 & 248 & 223 \\
\hline
\end{tabular}

$\mathrm{IOP}=$ intraocular pressure; $\mathrm{OCT}=$ optical coherence tomography.

intermediate uveitis and one had juvenile idiopathic arthritis. In these cases, local treatment is advantageous because systemic diseases are not masked, which enables accurate diagnosis and management in patients with subclinical disease. The dexamethasone implant controlled ocular inflammation and reduced macular edema, and had a mean duration of effect of 3.6 months. This effect duration was lower than the previously reported effect duration of 6 months $s^{(5)}$. One possible contribution to this difference may be related to previous anti-glaucomatous surgery in patients 1 and 3, which may have increased aqueous humor outflow and drug clearance.

Of the patients studied here, IOP only increased in patients with a history of glaucoma, and these increases may be related to steroid responsiveness. However, their IOP measures remained within the range of the general population following implantation. According to the American Academy of Ophthalmology, in normal individuals, IOP varies 2-6 mmHg over a 24-hour period. Perhaps these patients would have a greater increase in IOP if they had not undergone prior surgery. A possible treatment complication that we did not evaluate here is the development of cataract secondary to the use of a corticosteroid. We did not examine this because our follow-up period was not long enough, and controlled prospective studies are needed to examine this potential complication.

\section{CONCLUSION}

The dexamethasone 0.7-mg implant is effective and safe for the local treatment of chronic CME secondary to non-infectious intermediate uveitis and refractory to systemic steroids.

\section{REFERENCES}

1. van Kooji B, Rothova A, de Vries P. The pros and cons of intravitreal triamcinolone injections for uveitis and inflammatory cystoid macular edema. Ocul Immunol Inflamm. 2006;14(2):73-85.

2. Goldstein DA, Godfrey DG, Hall A, Callanan DG, Jaffe GJ, Pearson PA, et al. Intraocular pressure in patients with uveitis treated with fluocinoloneacetonide implants. Arch Ophthalmol. 2007;125(11):1478-85.

3. Williams GA, Haller JA, Kupperman BD, Blumenkranz MS, Weinberg DV, Chou C, Whitcup SM; Dexamethasone DDS Phase II Study Group. Dexamethasone posterior-segment drug delivery system in the treatment of macular edema resulting from uveitis or Irvine-Gass syndrome. Am J Ophthalmol. 2009;147(6):1048-54.

4. Haller JA, Kupperman BD, Blumenkranz MS, Williams GA, Weinberg DV, Chou C, Whitcup SM; Dexamethasone DDS Phase II Study Group. Randomized controlled trial of intravitreous dexamethasone drug delivery system in patients with diabetic macular edema. Arch Ophthalmol. 2008;128(3):289-96.

5. Lowder C, Belfort R Jr, Lightman S, Foster CS, Robinson MR, Schiffman RM, Li XY, Cu H, Whitcup SM; Ozurdex HURON Study Group. Dexamethasone intravitreal implant for noninfectious intermediate or posterior uveitis. Arch Ophthalmol. 2011;129(5):545-53.

6. Nascimento HM, França M, García LG, Muccioli C, Belfort R Jr. Subconjunctival dexamethasone implant for non-necrotizing scleritis. J Ophthalmic Inflamm Infect. 2013;3(1):7. 
7. Haller JA, Bandello F, Belfort R Jr, Blumenkranz MS, Gillies M, Heier J, Loewenstein A, Yoon YH, Jacques ML, Jiao J, Li XY, Whitcup SM; OZURDEX GENEVA Study Group. Randomized, sham-controlled trial of dexamethasone intravitreal implant in patients with macular edema due to retinal vein occlusion. Ophthalmology. 2010;117(6):1134-46.

8. Multicenter Uveitis Steroid Treatment Trial Research Group; Kempen JH, Altaweel MM, Holbrook JT, Jabs DA, Sugar EA. The multicenter uveitis steroid treatment trial: rationale, design, and baseline characteristics. Am J Ophthalmol. 2010;149(4):550-61.

9. Kempen JH, Daniel E, Dunn JP, Foster CS, Gangaputra S, Hanish A, et al. Overall and cancer related mortality among patients with ocular inflammation treated with immunosuppressive drugs: retrospective cohort study. BMJ. 2009:339:b2480.
10. BongartzT, Sutton AJ, Sweeting MJ, Buchan I, Matteson EL, Montori V. Anti-TNF antibody therapy in rheumatoid arthritis and the risk of serious infections and malignancies: systematic review and meta-analysis of rare harmful effects in randomized clinical trials. JAMA. 2006;295(19):2275-85. Erratum in: JAMA. 2006;295(21):2482. Comment in: JAMA. 2006:296(18):2205:ACP J Club. 2006:145(3):65: JAMA. 2006:296(18):2203: author reply 2203-4;JAMA. 2006;296(18):2201-2; author reply 2203-4; JAMA. 2006; 296(18):2201; author reply 2203-4; Arch Dermatol. 2007;143(3):405-6.

11. Andrade RE, Muccioli C, Farah ME, Nussenblatt RB, Belfort R Jr. Intravitreal triamcinolone in the treatment of serous retinal detachments in Vogt-Koyanagi-Harada syndrome. Am J Ophthalmol. 2004;137(3):572-4.

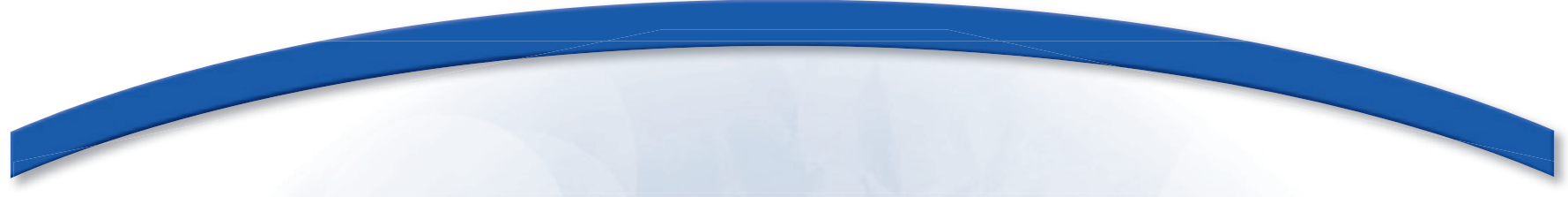

VIII Congresso Baiano de Oftalmologia

\author{
VI Congresso da Sociedade Brasileira \\ de Visão Subnormal
}

Congresso Brasileiro de Trauma Ocular

IX Congresso da Sociedade de Oftalmologia de Feira de Santana

\title{
VIII Simpósio LAOF
}

\section{2 e 3 de outubro de 2015}

Pestana Bahia Hotel

Salvador - BA

Informações:

Interlink Prime

Tel.: (71) 3011-9797

E-mail: indomar@interlinkeventos.com.br

Site: www.interlinkeventos.com.br 